MISCELLANEA
GEOGRAPHICA

Vol. 13/2008

pp. $11-19$

\begin{abstract}
Alina Gerlée
University of Warsaw - Faculty of Geography and Regional Studies - Department of Geoecology 00-927 Warsaw, Krakowskie Przedmieście 26/28

e-mail: a.gerlee@uw.edu.pl
\end{abstract}

\title{
STABILITY OF NATURAL SYSTEMS - THEORY AND PRACTICE
}

\begin{abstract}
The article discusses definitions and origin of the term "stability". A difference is made between the stability of systems and their equilibrium. Practical and theoretical application of the term and limitations of its application are presented. The idea of numerous states of stability and consequences related to its application in nature conservation are discussed.
\end{abstract}

Key words: stability of geoekosystems, definition of stability, idea of numerous states of stability

\section{INTRODUCTION}

An analysis of the term "stability" is carried out in the paper. Its objective is to familiarise with the term and to show the opportunities and limitations of its application. The definition of stability belongs to nominal definitions, that is those which specify the meaning of the term. Simultaneously, it is a reporting definition because in determining the meaning of the term, we can not refer to a specific convention defining its meaning. In reporting definitions we determine the meaning of a term in accordance to our own understanding (Ajdukiewicz 1974, based on Ostaszewska 2002). This is a necessary effort in order to avoid misunderstandings related to dissimilar understanding of the term. In defining the term "stability" a pragmatic criterion should be applied because the utility of the accepted definition is a significant element having impact on the effectiveness of further research. 


\section{THEORETICAL PRESENTATION OF THE TERM “STABILITY”}

The classical definition of "stability" refers to the mathematical function describing the state of the system. Conclusions stemming from this definition, however, have a much broader meaning than mathematical application (Richling \& Solon 2002).

Graph of the mathematical function $f(x)=a x(1-x)$, the so-called logistic curve, behaves in a specific manner. As the coefficient $a$ grows, we observe that the period increases two-fold which is visible as the bifurcation of the graph of conditions of determined functions. With $a$ greater than about $3,56994 \ldots$ systems begin to behave chaotically. Figure 1 shows a diagram of stable conditions of functions for coefficient $a$ from the range $[1,4]$. The term ,stability” should be distinguished from the term „equilibrium”. Both these terms, in reference to real systems, have no precise definitions. De Angelis \& Waterhouse (1987), to illustrate the difference between them, present a figure showing marbles situated in three different positions (A, B and C). In each case, the marble is at the equilibrium point but the points differ in stability. The grain placed in point $\mathrm{D}$ is not stable and is not at the equilibrium point. Force, with which we must impact a particular marble in order to disturb its equilibrium, is different in every case and the behaviour of the marbles will also be dissimilar. Impacting with small force upon the marble in point $\mathrm{B}$, we will disturb its state of equilibrium to which it will be impossible to return without assistance. On the other hand, the marble at point $\mathrm{A}$ is characterized by a relatively great stability. Under small disturbance it returns to its initial state of equilibrium. However, if we react with sufficiently big force and it will exceed a specific altitude on the slope, it will not be able to return to the initial location. The marble in point $\mathrm{C}$ behaves in a totally different manner. In result of external impact it moves a specific distance depending on the force which we place on it. It will not have an inclination to return to the initial state but will not be far removed from it.

In real systems it is not, of course, all that simple. The presented equilibrium models may be good starting points for discussion on the stability of geoekosystems.

The stability of geoekosystems (landscape) may be, in the most general terms, described as carrying on in time, under conditions of unchangeable surroundings and as an ability to return to the original state following the end of impact by disrupting factors. Such defini- 
tion was used in the Polish textbook on landscape ecology (Richling \& Solon 2002)

From the point of view of ecology, landscape stability is a dynamic phenomenon, characterised by an equilibrium relationship between endo and egzogenic as well as natural and anthropogenic processes and phenomena. Landscape is viewed as a complex system consisting of processes and phenomena, with a particular structure and function, existing in a specific place and time (Ružička at al. 1989).

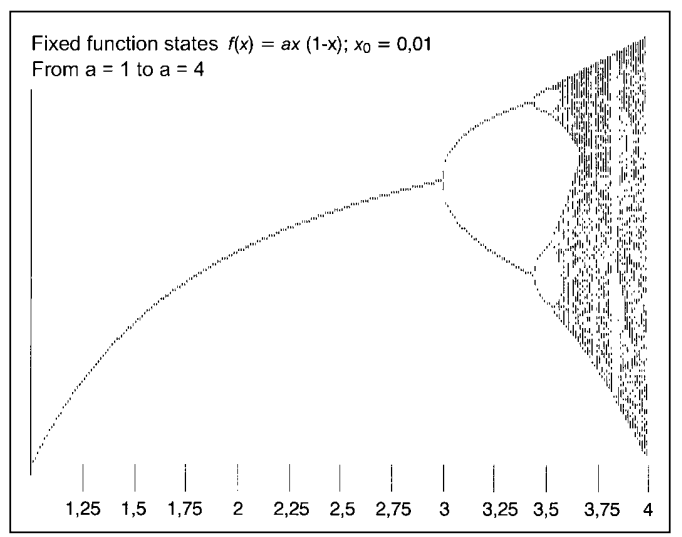

Fig. 1. Diagram of fixed states of logistic functions. (Source: Peitgen et al. 1996 based on Ostaszewska 2002)

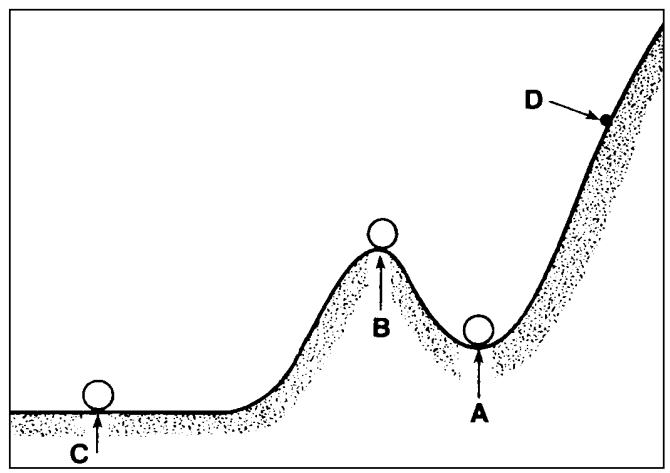

Fig. 2. Types of equilibrium points. $\mathrm{A}$ is in a stable equilibrium point, $\mathrm{B}$ is in an unstable equilibrium point and $\mathrm{C}$ is in a neutrally stable equilibrium point. Point $\mathrm{D}$ is not in the equilibrium point.

(Source: De Angelis \& Waterhouse 1987, changed) 
In landscape ecology the idea of "stability" is linked to diverse characteristics of geoekosystems. According to Richling (1976), besides stability in reference to particular stimuli, it is possible to discuss general stability. It defines resistance to or stability of natural systems in reference to all kinds of impact. Thus perceived, the concept comprises numerous system characteristics among which the most important are: equifinality, stability, inertia, resistance and elasticity. Equifinality is a principle which allows to reach the same end-result with different initial system development conditions. Stability is, in other words, invariability, i.e. stability in a particular time frame. Inertia is a delayed reaction of the system to disturbances. Resistance is a threshold value of parameters of surroundings, alongside which the system does not change or its changes are reversible. Elasticity defines the speed and manner of returning to the starting point following the end of disruption (Richling \& Solon 2002).

Pimm (1991, on the basis of Krebs 2001) singles out five principal meanings of the term "stability". The first refers to the mathematical concept of local stability and seems not to translate directly, by nature complex, (geo)ecosystems. Further on, he links stability with time needed for biocenosis to return to the primary state, following withdrawal of the disruption factor. This is in accordance with the etymological meaning of the idea. Also, the following two meanings of "stability" stem from the language definition of this idea and refer to the permanence and changeability in time of biocenosis. The author calls attention to the fact that the term "stability" is also used in describing the degree of change of total biocenosis under the influence of a change taking place in a part of it. Here, he introduces the term "resistance". As it seems, thus perceived "stability" may also be directly referred to landscape.

While discussing "stability" it is necessary to determine the referred to spatial and time range. Stability may be examined on numerous levels; i.e. the component level (components of the system), the ecosystem level (simple system) and the landscape level (ecosystem set - complicated system). Ružička et al. (1989) call attention to the fact that it is necessary to elaborate individual criteria for each level because stability does not exists as an universal quality. It rather is an operational concept aiming at determining the optimal solutions and showing the complexity of diverse processes in ecosystems.

Stability of the entire landscape and of a part of it is different. It is easier to transform smaller areas and they are more susceptible to 
the impact of disturbing factors. Transformation of fragments within a greater systems area does not have to lead to disturbance in functioning of the entire area. Small natural fires which are a natural phenomenon in some parts of the world may exemplify this. They totally transform parts of the landscape at the same time decreasing grand-scale fires which may be a significant factor in disturbing the entire system (O’Naill 2001).

Speaking of „stability” understood as resistance to internal disturbances it is also necessary to define what is a "disturbance". Krebs (2001) defines it as an occurrence which disturbs the biocenosis structure and changes the availability of resources, biocenosis structure or the physical environment. Both egzo and endogenic disturbances, as well as all intermediary forms, may be measured in different ways. It is important to guarantee the proper perspective for description of the disturbance, both in time and in space. The author lists several disturbance measures for which definitions are listed in table 1.

Tab. 1.

Definitions of disturbance measures

\begin{tabular}{|c|l|}
\hline Measure & \multicolumn{1}{c|}{ Definition } \\
\hline Distribution & $\begin{array}{l}\text { Spatial distribution, including dependence on geographic, } \\
\text { topographic, environmental and biocenotic slopes }\end{array}$ \\
\hline Frequency & Mean number of occurrences in a given time \\
\hline Period & Frequency reversal, mean time between disturbances \\
\hline Cycle length & $\begin{array}{l}\text { Mean time needed to evoke disturbance on a surface being } \\
\text { counterpart of the examined area (examined area must be } \\
\text { defined) }\end{array}$ \\
\hline Predictability & Reversal of variability in periods between occurrences \\
\hline Size, intensity & $\begin{array}{l}\text { Disturbed area. May be expressed as the disturbance area, } \\
\text { size of the area per time unit, total area per given type of } \\
\text { disturbance per time unit }\end{array}$ \\
\hline Acuteness & $\begin{array}{l}\text { Physical force of disturbance per area in time unit (e.g. wind } \\
\text { velocity in case of hurricane) }\end{array}$ \\
\hline Effect on biocenosis (e.g. basic destructed area) \\
\hline Synergy & $\begin{array}{l}\text { Influence on occurrence of other disturbances (e.g. drought } \\
\text { influences frequency of fires or damages caused by insects } \\
\text { increase hurricane susceptibility) }\end{array}$ \\
\hline
\end{tabular}

Source: Krebs 2001,changed 


\section{STABILITY IN PRACTICE}

The idea of stability of natural systems is applied in environmental management. In the works of Slovak authors the idea of "stability" is often understood as permanence of the ecosystem, as its constant. The method for territorial system of ecological stability (TSES) was introduced as the binding procedure in spatial planning in Slovakia. It includes territorial classification comprising stability of territory (EST). It includes three main elements in which a given territory is assigned a category in the scale of 1-5. The first element is the territory covering. In assigning categories the degree of anthropogenic transformation is considered. The second is legal protection which considers the area of the territory being protected and the protection regimen. The third considers the anthropogenic disturbance factors. The scale takes under consideration factor assessment, depending on their kind and the foreseeable cumulated impact effect (Hrnčiarová \& Ružička 1997). Topercer (1995) faults this method with, among others, with the fact that it do not pay sufficient attention to field research and that the research teams do not include biologists and ecologists.

For description of natural systems is also used the concept of numerous stability states stemming from the idea of stability. This idea refers to the behaviour of the logistic curve (Fig. 1). It assumes that some of the biocenosis may have several states in which they maintain stability. As an example, wooded areas within national parks and reserves in East Africa may be given. Their area has significantly diminished in the last 30 years. There are data which allow to explain these changes as the result of cooperation of two factors. In the sixties of the $\mathrm{XX}^{\text {th }}$ century, every year the Serengeti territory was affected by intensive fires, burning out over half of its territory. Throughout this territory, in the eighties, there significantly increased the number of gnu antelopes and elephants. During the dry season, the gnu consumed enough grass to considerably limit the area of the fires. It decreased from over $60 \%$ to $5 \%$.

However, currently, the regrowth of the forest is impeded by the presence of a sizeable elephant population feeding on young trees. If the elephants and gnus will be exterminated, the frequency of fires will increase and the territories will continue as a grass community. The return of the forests will be possible only under circumstances when, at the same time, there will not be intensive fires and elephants (Dublin 
at al. 1990 based on Krebs 2001). Therefore, these territories may continue being either a forest community or non-forest areas, depending upon the presence or absence of two large herbivorous species. Also, in other natural systems transformed by man there may be several states of stability. In certain cases following termination of functioning of the anthropogenic factor they may return to the initial configuration and in others, however, they may totally change their shape (Krebs 2001).

Baker \& Walford (1995) indicate a certain danger related to the idea of numerous states of stability. These states occur relatively seldom in natural conditions and usually are associated with the coming about of a disturbance factor of strong force which may not be recognized as a typical change of the environment. Such a factor may be, for example, a flood or other disaster. Disturbances of a comparably strong force may also be the result of man's activity. The authors call attention to the fact that some of the systems transformed by man have numerous states of stability. This does not signify, however, that in shaping the environment one may freely select between these states, being guided by people's interest and not knowledge about the potential vegetation of a given territory. They give, as a negative example, the review of the ecosystem condition assessment method published by the National Research Council's (1994, based on Baker \& Walford 1995). In conclusions of the quoted publication, it is written that similarities between the current species composition and biomass production and climax plant community (SCS) or potential natural community (USFS, BLM) should not serve as basis for assessment of the health condition of the environment. And more, their similarity should not even be a part of such assessment. Taking under consideration numerous models of stability states poorly managed or strongly transformed areas could be assessed as being well functioning.

\section{CONCLUSIONS}

The term „stability” does not have a one generally accepted definition. Authors using it in their research individually define the manner of understanding it and the scope of its use. It is worthy to note that by using the term ,stability” we only define some of the characteristics of the system. Using them in examining natural systems as well as an auxiliary instrument in environmental management and spatial 
planning it should be remembered that it only is a thought construction and not a measurable parameter.

Number measures of stability, sometimes used by researchers, should be dealt with in a relative manner. Applying specific measures we may identify which (geo)ecosystems are more or less stable in regard to something. It depends upon what parameters will be taken into consideration.

Determining the stability of a system in detachment from its potential, natural relationships with surrounding areas and ecological functions may lead to erroneous conclusions on the functioning of naturalness of a given ecosystem. It may have serious meaning in the case of communities which we want to protect because of specific functions or characteristics. Both, fully developed "stable" ecosystems and "unstable" systems sensitive to disturbances and impermanent, are protected. Therefore, stability of the natural system should not be an evaluative element but rather one which indicates the type of conservation and (geo)ecosystem sensitivity.

\section{REFERENCES}

Baker W.L., G. M. Walford, 1995, Multiple stable states and models of riparian vegetation succession on the Animas River, Colorado. Annals of the Association of American Geographers 85 (2): 320-338.

De Angelis D.L., J.C. Waterhouse, 1987, Equilibrium and Nonequilibrium Concepts in Ecological Models. Ecological Monographs 57: 1-21.

Dublin, L. I., A.R.E. Sinclair, J. McGlade, 1990, Elephants and fire as causes of multiple stable states in the Serengeti-Mara woodlands. Journal of Animal Ecology 59: 1147-1164.

Hrnčiarová T., M. Ružička, 1997, Classification of the ecological stability of the territory. Ekológia (Bratislava): 16 (1): 81-98.

Krebs C. J., 2001, Ekologia. Eksperymentalna analiza rozmieszczenia i liczebności [Experimental analysis of distribution and number, in Polish]. Wydawnictwo Naukowe PWN, Warszawa.

O'Naill R. V., 2001, Is it time to bury the ecosystem concept? (with full military honors, of course!). Ecology 82(12): 3275-3284.

Ostaszewska, K., 2002, Geografia krajobrazu [Landscape geography; in Polish]. Wydawnictwo Naukowe PWN, Warszawa.

Ostaszewska K., 2005, Krajobraz - środowisko geograficzne - środowisko przyrodnicze [Landscape - geographic environment - natural environment; in Polish]. [w:] Geografia jako nauka o przestrzeni, środowisku i krajobrazie, 2005, W. Maik, K. Rębowska, A. Suliborski (eds.), Łódzkie Towarzystwo Naukowe, Łódź. 
Richling A., 1976, Analiza struktury środowiska geograficznego $i$ nowa metoda regionalizacji fizycznogeograficznej [Analysis of the geographic environment structure and the new method of physicogeographic regionalization; in Polish]. Rozprawy UW 104, Warszawa.

Richling A., J. Solon, 2002, Ekologia krajobrazu [Landscape geography; in Polish]. Wydawnictwo Naukowe PWN, Warszawa.

Ružička M., A. Jurko, M. Kozova, F. Žigrai, V. Svetlosanov, 1983, Evaluation methods of Landscape Stability on agricultural territories in Slovakia, Ekológia (CSSR) 2, 3.

Topercer J., Jr., 1995, Ecological comments on territorial systems of ecological stability. Ekológia (Bratislava) 14 (3): 303-315.

English translation: Małgorzata Miłaszewska 